Wiryanto et.al. Increasing knowledge and community attitude in doing Swamedication through extension

\title{
Increasing knowledge and community attitude in doing Swamedication through extension
}

\author{
Wiryanto $^{1 *}$, Julia Reveny ${ }^{1}$, Juanita Tanuwijaya ${ }^{1}$, Edy Suwarso $^{1}$, Surjanto ${ }^{1}$ \\ ${ }^{1}$ Department of Pharmachy, Faculty of Pharmachy, Universitas Sumatera Utara \\ *Email: Wiryanto_2510@yahoo.com
}

\begin{abstract}
Based on various field studies it is known that many members of the community still lack sufficient knowledge and attitudes to carry out swamedications. Self-medication or self-medication is defined as the use of drugs without professional supervision, to treat health problems with symptoms that are self-identified, recurrent illnesses or minor health problems. Community service is aimed at increasing public knowledge and attitudes about self -ication through counseling. Counseling is addressed to administrators, employees, teachers, and students of the Al Razi Sinar Harapan Education Foundation, having its address at Jl. Eka Rasmi, Melinjo I No. 19 Medan. The counseling activities involved 50 participants, starting with the provision of knowledge materials and attitudes about self-medication, demonstration of various markings on pharmaceutical preparations, introduction of pharmacist figures as community guides in various drug-related problems and their proper use, closed with a question and answer session with prizes. To find out the benefits of counseling in increasing knowledge and attitudes about self-medication, before and after counseling, participants were asked to fill out a questionnaire. Based on the evaluation of filling out the questionnaire before and after counseling, it is known that in general there was an increase in the average points (criteria) of knowledge and attitudes from the previous 44.71 and 41.76 (less) to 56.47 and 52.94 (enough). In more detail, the increase in the mean points (criteria) of knowledge and attitudes of the foundation management group and teachers increased from points 57.14 and 40 (less) to 77.14 (good) and 62.86 (sufficient). From the group of high school students increased from 31.11 and 42.22 points (less) to 60.00 and 64.44 (enough). And from the group of junior high school students increased from 44.71 and 41.76 points (less) to 56.47 and 52.94 (enough). From the results of the evaluation it can be concluded that the extension activities are proven to be able to increase the knowledge and attitudes of the community in conducting self-authentication.
\end{abstract}

\section{Keywords: Medicine, Drug Use, Knowledge, Attitude, Self-Medication}

\begin{abstract}
Abstrak
Berdasarkan berbagai penelitian di lapangan diketahui bahwa banyak anggota masyarakat yang masih kurang memiliki pengetahuan dan sikap yang cukup untuk melakukan swamedikasi. Swamedikasi atau self medication didefinisikan sebagai penggunaan obat tanpa pengawasan profesional, untuk mengobati gangguan kesehatan dengan gejala-gejala yang dikenali sendiri, penyakit berulang atau masalah kesehatan yang bersifat ringan. Pengabdian kepada masyarakat ini bertujuan meningkatkan pengetahuan dan sikap masyarakat tentang swamedikasi melalui penyuluhan. Penyuluhan ditujukan kepada pengurus, pegawai, guru, dan siswa Yayasan Pendidikan Al Razi Sinar Harapan, beralamat di Jl. Eka Rasmi, Melinjo I No. 19 Medan. Kegiatan penyuluhan melibatkan 50 peserta, dilakukan mulai dari pemberian materi pengetahuan dan sikap tentang swamedikasi, peragaan berbagai penandaan pada sediaan farmasi, pengenalan sosok apoteker sebagai pemandu masyarakat dalam berbagai masalah terkait obat dan penggunaannya secara tepat, ditutup dengan sesi tanya-jawab berhadiah. Untuk mengetahui manfaat penyuluhan dalam meningkatkan pengetahuan dan sikap tentang swamedikasi, sebelum dan sesudah penyuluhan, kepada peserta diminta mengisi kuesioner. Berdasarkan evaluasi pengisian kuesioner sebelum dan sesudah penyuluhan, diketahui bahwa secara umum terjadi peningkatan rerata poin (kriteria) pengetahuan dan sikap dari yang sebelumnya 44,71 dan 41,76 (kurang) menjadi 56,47 dan 52,94 (cukup). Secara lebih rinci peningkatan rerata poin (kriteria) pengetahuan dan sikap dari kelompok pengurus yayasan dan guru meningkat dari poin 57,14 dan 40 (kurang) menjadi 77,14 (baik) dan 62,86 (cukup). Dari kelompok siswa SLTA meningkat dari poin 31,11 dan 42,22 (kurang) menjadi 60,00 dan 64,44 (cukup). Dan dari kelompok siswa SLTP meningkat dari poin 44,71 dan 41,76 (kurang) menjadi 56,47 dan 52,94 (cukup).Dari hasil evaluasi dapat disimpulkan bahwa kegiatan penyuluhan ini terbukti mampu meningkatkan pengetahuan dan sikap masyarakat dalam melakukan swamedikasi
\end{abstract}

Kata kunci: Obat, Penggunaan Obat, Pengetahuan, Sikap, Swamedikasi 
Wiryanto et.al. Increasing knowledge and community attitude in doing Swamedication through extension

\section{PENDAHULUAN}

Kesehatan adalah keadaan sehat, baik secara fisik, mental, spritual maupun sosial yang memungkinkan setiap orang untuk hidup produktif secara sosial dan ekonomis (Pemerintah RI., 2009). Seiring dengan kemajuan teknologi dan perubahan pola hidup masyarakat yang cenderung kurang memperhatikan kesehatan, maka keberadaan penyakit yang semakin beragam di masyarakat tidak dapat dielakkan. Keberadaan penyakit yang semakin beragam mendorong pemerintah untuk melakukan penyediaan obat yang bermutu dan berkasiat, serta aman pada penggunaannya. Untuk meningkatkan keamanan dan ketepatan penggunaan serta untuk pengamanan distribusi, pemerintah membagi obat menjadi berbagai golongan masing-masing dengan penandaan yang mudah dikenali sebagai rambu-rambu penggunaan obat, baik pengguna langsung maupun provider kesehatan (Menkes RI.,1990; Menkes RI., 1993; Menkes RI., 2015a; Menkes RI., 2015b; Ka BPOM RI., 2016).

Disamping itu untuk masyarakat luas, Ditjen Binfarkomnik Kementerian Kesehatan RI juga telah menerbitkan buku Pedoman Penggunaan Obat Bebas dan Bebas Terbatas (Direktur Binfarkomnik, 2006), sebagai pedoman melakukan swamedikasi. Swamedikasi (self medication) didefinisikan sebagai penggunaan obat tanpa pengawasan profesional, untuk mengobati gangguan kesehatan dengan gejala-gejala yang dikenali sendiri, penyakit berulang atau masalah kesehatan yang bersifat ringan (Jain, dkk., 2011). Untuk kalangan tenaga kesehatan, organisasi profesi Ikatan Apoteker Indonesia (IAI) telah menerbitkan Informasi Spesialite Obat (ISO) Indonesia secara periodik (Kasim, 2015). Dengan penandaan obat yang mudah dikenali dan dengan tersedianya buku-buku pedoman, masyarakat pengguna obat diharapkan dapat memperoleh pengobatan yang aman terkait risiko, efektif terkait terapi, dan efisien terkait biaya.

Pada kenyataannya, pelaksanaan pengobatan di masyarakat masih belum sepenuhnya memperhatikan rambu-rambu yang telah ditentukan, terutama kaitannya dengan swamedikasi. Karena keterbatasan pengetahuan tentang obat dan penggunaannya, pelaksanaan swamedikasi dapat menjadi sumber terjadinya penyalahgunaan obat (drug abuse) (Ikawati, 2009), kesalahan penggunaan obat (drug misuse) (Dika, 2015), dan kesalahan pengobatan (medication error) (Engga, 2013). Masyarakat cenderung hanya tahu merek dagang obat tanpa tahu isi zat berkhasiatnya, lebih memilih obat yang diinginkan ketimbang memilih obat yang dibutuhkan. Pelayanan obat lebih sering dilakukan oleh siapa saja dengan karkter "pedagang" ketimbang dilakukan oleh provider kesehatan dengan karakter "profesional". Obat lebih sering dipandang sebagai komoditas biasa, bukan sebagai komoditas khusus yang mempunyai risiko bagi penggunanya (Wiryanto, 2009).

\section{METODE}

Kegiatan penyuluhan dilakukan mulai dari pemberian materi pengetahuan dan sikap tentang swamedikasi, peragaan berbagai penandaan pada sediaan farmasi, pengenalan sosok apoteker sebagai pemandu masyarakat dalam berbagai masalah terkait obat dan penggunaannya secara tepat, ditutup dengan sesi tanya-jawab berhadiah. Untuk mengetahui manfaat penyuluhan dalam meningkatkan pengetahuan dan sikap tentang swamedikasi, sebelum dan sesudah penyuluhan, kepada peserta diminta mengisi kuesioner.

\section{HASIL DAN PEMBAHASAN (RESULTS AND DISCUSSION)}

Hasil evaluasi pengetahuan dan sikap peserta sebelum dan sesudah penyuluhan ditunjukkan pada diagram 3.1 dan diagram 3.2 di bawah ini: 
Wiryanto et.al. Increasing knowledge and community attitude in doing Swamedication through extension

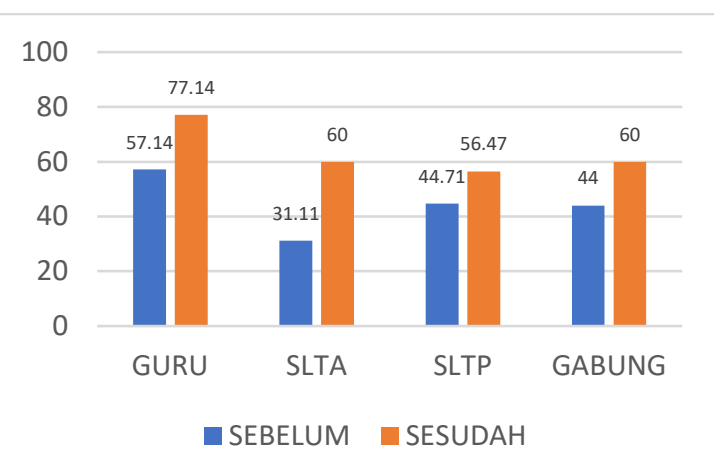

Gambar 1. Hasil evaluasi pengetahuan sesudah dan sebelum penyuluhan

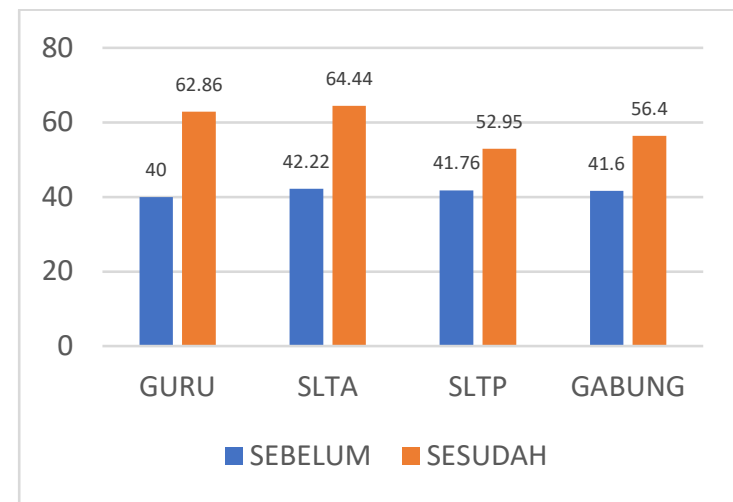

Gambar 2. Hasil evaluasi sikap sesudah dan sebelum penyuluhan

Berdasarkan evaluasi pengisian kuesioner sebelum dan sesudah penyuluhan, diketahui bahwa secara umum terjadi peningkatan poin (kriteria) pengetahuan dan sikap dari yang sebelumnya 44,71 dan 41,76 (kurang) menjadi 56,47 dan 52,94 (cukup). Secara lebih rinci peningkatan poin (kriteria) pengetahuan dan sikap dari kelompok pengurus yayasan dan guru meningkat dari poin 57,14 dan 40 (kurang) menjadi 77,14 (baik) dan 62,86 (cukup). Dari kelompok siswa SLTA meningkat dari poin 31,11 dan 42,22 (kurang) menjadi 60,00 dan 64,44 (cukup). Dan dari kelompok siswa SLTP meningkat dari poin 44,71 dan 41,76 (kurang) menjadi 56,47 dan 52,94 (cukup).

Dari hasil evaluasi pengetahuan setelah penyuluhan kelompok guru memperoleh poin teratas $(77,14)$ dengan kriteria baik dibanding kelompok siswa SLTA $(60)$ maupun siswa SLTP $(56,47)$ dengan kriteria cukup, dapat dilihat bahwa kelompok guru dan kelompok siswa mempunyai selisih yang cukup jauh yaitu antara 17 hingga 21 poin. Hal ini dapat difahami bahwa kelompok guru yang kebanyakan berpendidikan sarjana ini tentu lebih mempunyai kemampuan menerima pengetahuan dengan lebih baik. Perolehan poin pengetahuan (kognitif) kelompok guru setelah penyuluhan dengan kriteria baik ternyata belum diikuti perolehan poin sikap (motirik) yang hanya mencapai kriteria cukup. Hal ini dapat dijelaskan bahwa sikap sudah memasuki area melakukan tindakan, yang membutuhkan tanbahan pengalaman dan kematangan untuk melakukan.

Pengetahuan Ilmu Kefarmasian merupakan pengetahuan khusus yang menopang keahlian sebuah profesi, bukan pengetahuan yang umum diketahui masyarakat. Sehingga meskipun kelompok guru mempunyai pengetahuan umum dan pengalaman yang sudah pasti lebih tinggi dari siswanya, tetapi pada masalah khusus masih belum dapat dipastikan. Hasil evaluasi sikap setelah penyuluhan tidak menunjukkan perbedaan yang cukup jauh, perolehan poin kelompok guru 62,86 kelompok siswa SLTA 64,44 dan kelompok sisws SLTP 52,95 ketiganya termasuk dalam kriteria cukup.

Selanjutnya peningkatan poin sebelum dan sesudah dari masing-masing kelompok dan keseluruhan kelompok/gabung dapat dilihat pada diagram 3.3 berikut ini: 
Wiryanto et.al. Increasing knowledge and community attitude in doing Swamedication through extension

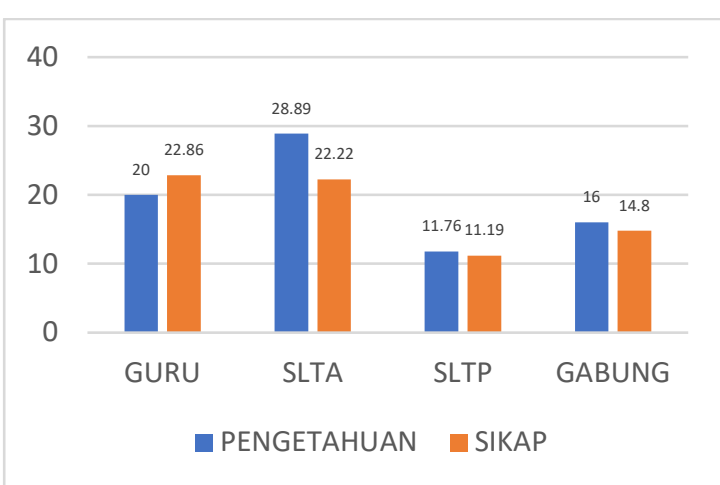

Gambar 3. Peningkatan poin pengetahuan dan sikap sesudah dan sebelum penyuluhan

Peningkatan pengetahuan tertinggi terjadi pada kelompok siswa SLTA $(28,89)$ hal ini disebabkan karena pengetahuan sebelum penyuluhan kelompok ini relatif rendah $(31,11)$ yang kemudian ada hal baru yang mudah difahami serta menyangkut kehidupan sehari-hari menghasilkan capaian poin kuesioner yang relatif tinggi. Kelompok guru mempunyai peningkatan pengetahuan kedua setelah kelompok siswa SMA (20) hal ini disebabkan karena pengetahuan kelompok ini sebelum penyuluhan sudah cukup tinggi $(57,14)$ peningkatan pengetahuan maksimal dicapai 20 poin, selebihnya adalah pertanyaan-pertanyaan yang cukup sulit atau terdengar asing. Kelompok siswa SLTP mempunyai peningkatan pengetahuan terendah $(11,76)$ hal ini disebabkan banyak pertanyaan yang cukup sulit atau terdengar asing.

\section{CONCLUSION}

Dari hasil evaluasi dapat disimpulkan bahwa kegiatan penyuluhan ini terbukti mampu meningkatkan pengetahuan dan sikap masyarakat dalam melakukan swamedikasi

\section{ACKNOWLEDGMENT}

Kegiatan pengabdian masyarakat dosen wajib mengabdi telah dapat diselesaikan dengan sebaikbaiknya. Pada kesempatan ini, tim pelaksana pengabdian mengucapkan terimakasih yang sebesarbesarnya kepada LPPM yang telah membiayai kegiatan ini

\section{REFERENCES}

Dika. 2015. 7 Kasus Kesalahan Penggunaan Obat yang Fatal Versi Lingkar Studi. [diakses 14 Juli 2016] https://www.usd.ac.id/blog/lingkarstudi/?p=26

Direktur Binfar Komnik. 2006. Pedoman Penggunaan Obat Bebas dan Bebas Terbatas. Jakarta: Departemen Kesehatan RI.

$\begin{array}{llllllll}\text { Engga, } & \text { S. 2013. Medication } & \text { Error. } & \text { [diakses } & 14 & \text { Juli } & \text { 2016] }\end{array}$ http://egacuman1.blogspot.co.id/2013/07/medication-error.html

Ikawati, Z. 2009. Tinjauan farmakoterapi terhadap penyalahgunaan obat. [diakses 14 Juli 2016] https://zulliesikawati.wordpress.com/tag/penyalahgunaan-obat/

Jain, S., Malvi,R., dan Purviya, JK. 2011. Concept of Self Medication: A Review. International Journal of Pharmaceutical \& Biological Archives. 2(3):831-836

Kasim, F. 2016. Informasi Spesialite Obat Indonesia, Volume 50. Jakarta: ISFI Penerbitan 
Wiryanto et.al. Increasing knowledge and community attitude in doing Swamedication through extension

Kepala Badan Pengawas Obat dan Makanan RI. 2016. Peraturan Kepala Badan Pengawas Obat dan Makanan RI No.7 Tahun 2016 tentang Pedoman Pengelolaan Obat-Obat Tertentu Yang Sering Disalahgunakan. Jakarta: Badan Pengawas Obat dan Makanan RI.

Menkes RI. 1990. Kepmenkes RI No.347/MenKes/SK/VII/1990 tentang Obat Wajib Apotek. Jakarta: Departemen Kesehatan RI.

Menkes RI. 1993. Permenkes RI No.917/Menkes/Per/X/1993 tentang Wajib Daftar Obat Jadi. Jakarta: Departemen Kesehatan RI.

Menkes RI. 2015ª Permenkes RI No.3 Tahun 2015 tentang Peredaran, Penyimpanan, Pemusnahan, dan Pelaporan Narkotika, Psikotropika, dan Prekursor Farmasi. Jakarta: Kementerian Kesehatan RI.

Menkes RI., 2015 . Permenkes RI No.9 Tahun 2015 tentang Perubahan Penggolongan Psikotropika. Jakarta: Kementerian Kesehatan RI.

Pemerintah RI., 2009. Undang-undang RI No.36 Tahun 2009 tentang Kesehatan.Jakarta: Lembaran Negara RI tahun 2009 No.144.

Wiryanto. 2009. Kompetensi Apoteker dan Profil Pelayanan Kefarmasian di Apotek Pasca Puka di Kota Medan. Jakarta: Kongres Ilmiah ISFI XVII, 7-8 Desember 2009. 